DOSSIÊ TEMÁTICO: Educação, currículo e juventudes: dilemas e desafios atuais

do] https://doi.org/10.22481/praxisedu.v16i42.7354

\title{
BASIC DIGITAL LITERACY - REQUIREMENTS AND ELEMENTS
}

\author{
ALFABETIZAÇÃO DIGITAL BÁSICA - REQUISITOS E ELEMENTOS
}

ALFABETIZACIÓN DIGITAL BÁSICA: REQUISITOS Y ELEMENTOS

Ilka Koppel
University of Education Weingarten - Germany

Sandra Langer

University of Education Weingarten - Germany

\begin{abstract}
Participation in society requires not only literary and mathematical basic education but also basic digital literacy (COULDRY \& HEPP, 2016; BMBF \& KMK, 2016). Current research indicates that low literary and low digital competences are linked (Wolf \& Koppel, 2017; BUDDEBERG, 2019). 6.2 million adults with low literality live in Germany (GROTLÜSCHEN et al., 2019). These people may be able to write and understand words or simple sentences when reading, but neither longer sentences nor coherent texts. However, this results in a considerable risk of exclusion from participation in various areas of life (work, finance, housing, informed decision) (BUDDEBERG, 2019). Due to technological developments, people with a low level of digital literacy are systematically (partially) excluded from participation in society in most parts of the world. This leads to the question of what it is that defines digital literacy in order not to be excluded from society because of low digital literacy. In this article we discuss what digital literacy is - including the concept of competence - and what elements basic digital literacy encompasses.
\end{abstract}

Key words: digital, digital literacy, competences, digital inclusion

Resumo: A participação na sociedade requer não apenas educação básica literária e matemática, mas também alfabetização digital básica (COULDRY \& HEPP, 2016; BMBF \& KMK, 2016). Pesquisas atuais indicam que baixas competências literárias e digitais estão vinculadas (WOLF \& KOPPEL, 2017; BUDDEBERG, 2019). 6,2 milhões de adultos com baixa literalidade vivem na Alemanha (GROTLÜSCHEN et al., 2019). Essas pessoas podem ser capazes de escrever e entender palavras ou frases simples ao ler, mas nem frases mais longas nem textos coerentes. No entanto, isso resulta em um risco considerável de exclusão da participação em várias áreas da vida (trabalho, finanças, moradia, decisão informada) (BUDDEBERG, 2019). Devido ao desenvolvimento tecnológico, pessoas com baixo nível de alfabetização digital são sistematicamente (parcialmente) excluídas da participação na sociedade na maior parte do mundo. Isso leva à questão do que define a alfabetização digital para não ser excluído da sociedade por causa da baixa alfabetização digital. Neste artigo, discutimos o que é alfabetização digital - incluindo o conceito de competência - e quais elementos a alfabetização digital básica abrange.

Palavras-chave: digital, alfabetização digital, competências, inclusão digital 
Resumen: La participación en la sociedad requiere no solo educación básica literaria y matemática, sino también alfabetización digital básica (couldry y hepp, 2016; BMBF y KMK, 2016). La investigación actual indica que las bajas competencias literarias y digitales están vinculadas (WOLF y KOPPEL, 2017; BUDDEBERG, 2019). 6.2 millones de adultos con baja literalidad viven en Alemania (GROTLÜSCHEN et al., 2019). Estas personas pueden escribir y comprender palabras u oraciones simples al leer, pero ni oraciones más largas ni textos coherentes. Sin embargo, esto conlleva un riesgo considerable de exclusión de la participación en diversas áreas de la vida (trabajo, finanzas, vivienda, decisión informada) (BUDDEBERG, 2019). Debido a los desarrollos tecnológicos, las personas con un bajo nivel de alfabetización digital son sistemáticamente (parcialmente) excluidas de la participación en la sociedad en la mayor parte del mundo. Esto lleva a la pregunta de qué es lo que define la alfabetización digital para no ser excluido de la sociedad debido a la baja alfabetización digital. En este artículo discutimos qué es la alfabetización digital, incluido el concepto de competencia, y qué elementos abarca la alfabetización digital básica.

Palabras clave: digital, alfabetización digital, competencias, inclusión digital.

\section{Requirements for Adults in a Deeply Mediatized World}

Technological change in general and principally the increasing presence of ICT (information and communication technologies) in all aspects of life can be recognized in all countries. Digital media have changed our communication in the last decades. At the same time, media not only have an effect on the practices of the members of a society, but individuals also change the composition of the media through their appropriation of media (cf. WOLF 2017). Without an ability to acquire and use digital media, people can only make everyday activities, such as banking, more difficult or obtain comprehensive information. New risks also arise, such as identity theft or manipulation by fake news. The question arises as to what skills and abilities one must have in relation to digital media in order to be able to shape everyday life in a self-determined way.

In addition to that, changes in the employment structure have already led to a growing demand for advanced cognitive skills involving the understanding, interpretation, analysis and communication of complex information in the early 2010 th (NATIONAL TRAINING STRATEGY, 2019, p. 9; OECD, 2012; STURM, 2010). Already basic skills, such as the ability to extract content from texts or to use and interpret numerical information (VÁGVÖLGYI et al., 2016) are required in order to participate actively and successfully in social life (RAMMSTEDT, 2013). Therefore, adult education plays a vital role by supporting people in developing with necessary competences. Personal and professional development is promoted so that individuals can take control of their lives (UNESCO, 2016). 
Germany is one of the leading countries in the world in terms of quality, funding and participation in adult education. It is among the 19 percent of countries that invest more than 4 percent of their education budget in lifelong learning (UNESCO INSTITUTE FOR LIFELONG LEARNING, 2016). What seems to be an outstanding vote for German adult education does not show the 6.2 million adults with low literacy skills living in Germany (GROTLÜSCHEN et al., 2019). People with low literacy skills might write and understand words or even simple sentences, but neither longer sentences nor coherent texts (GROTLÜSCHEN et al., 2019; VÁGVÖLGYI et al., 2016). However, participation in society requires not only literary and mathematical basic education, financial and health education, but also skills in dealing with digital media (COULDRY \& HEPP, 2016; BMBF \& KMK, 2016; TRÖSTER \& SCHRADER, 2016; see also KAMIN \& MEISTER, 2013). Current research indicates that low literacy and low digital competences are linked (WOLF \& KOPPEL, 2017; BUDDEBERG, 2019; VÁGVÖLGYI et al., 2016). This results in a considerable risk of exclusion from participation in various areas of life, e.g. work, finance, housing or informed decision making (BUDDEBERG, 2019).

Therefore, a stronger integration of digital technologies in adult education is advocated (EUROPEAN COMMISSION, 2015; HELBIG \& HOFHUES, 2018; KERRES, 2013; PIETRAß, 2015). ICT are also seen as holding great potential for improving access by adults to a variety of learning opportunities as they offer multiple innovative possibilities permitting individualized learning. Adult learners can learn anytime and anywhere through computers, tablets, e-books, and mobile technology, electronic networking, social media and online courses (UNESCO, 2016; UNESCO Institute for Lifelong Learning, 2016). Especially adults in basic education can benefit from the use of digital media (LIN et al., 2017; WOLF \& KOPPEL, 2017).

Hence, minimizing the risk of exclusion, people need skills in dealing with digital media. This demand leads to the following questions: What is Basic Digital Literacy? Which preconditions are required in order to efficiently use digital technology for participating in society?

In a culture characterized by a profound mediatization, an elementary rethinking of the requirements for basic education is necessary. This is not a matter of a structure-preserving addition, e.g. from reading to digital reading, but of a fundamental change in basic cultural skills. In contrast to reading, writing and arithmetic, the fourth (digital) cultural technique, which has yet to be defined, is much more complex and difficult to determine. 
The requirement for a basic digital literacy thus arises from two perspectives: On the one hand, the reference point is the requirements for social participation. In concrete terms, the question must be asked here: What media-related skills does an adult person need in order to participate in social life? The starting point here is the individual in his or her socio-cultural context. It is therefore a relative requirement.

On the other hand, competence models define and make verifiable the requirements that people need in order to become media competent. These competence models are primarily considered in the school context with the premise of helping pupils to become responsible citizens and preparing them for the labour market. In the competence models, the development goals are operationalised and thus made objectively testable. This is an objectified requirement for people with regard to media-related skills.

In conclusion, the concept of a basic digital literacy can be determined on the one hand by the requirements which arise rationally in order to be able to participate in society and on the other hand by the development goals which can be determined objectively. Both approaches are relevant. Herafter we will explore, which aspects of the two approaches are fruitful for a concept of basic digital literacy.

\section{The Objectivist View - Concept of Digital Competence}

Looking at the current discussion regarding new educational requirements in a digital world or culture, it is striking that the dominant approaches are based on objectivist competence models or material educational canons in order to make them measurable and thus comparable in terms of educational policy. The idea of objectivism is that there is a correct way to do things which can be discovered by following the objective methods of science. The understanding of competencies is the possibility of the analysis of discrete, observable, measurable, behaviour. These behaviours are understood as verifiable performance indicators and acted as evidence that a particular skill has been 'performed'.

According to this, several definitions and operationalized models exist. In 2006 digital competence was recognized by the European Parliament and the European Council as one of eight key competences to master in a knowledge-based society. Digital competence was defined as follows:

"Digital competence involves the confident and critical use of information Society technology (IST) for work, leisure, learning and communication. It is underpinned by basic 
skills in ICT: the use of computers to retrieve, access, store, produce, present and exchange information, and to communicate and participate in collaborative networks via the Internet."

For example, the PIAAC study (Programme for the International Assessment of Adult Competencies) for the investigation of basic adult competencies defines technology-based problem solving as the competence to successfully use digital technologies, communication aids and networks to search for, convey and interpret information (RAMMSTEDT 2013, 12). In the "International Computer and Information Literacy Study" (ICILS), which however only tests students in the 8th grade, computer and information-related competencies are also defined as the ability to search for information in the Internet, to evaluate it with regard to its quality and usefulness or to use information and communication technologies responsibly and reflectively.

All competence frameworks use level models based on cognitive claim levels in the sense of Bloom's taxonomy levels. In the "Media Competence Framework NRW" of Germany (https://medienkompetenzrahmen.nrw/), for example, the cognitive level of requirements for primary school pupils is predominantly limited to the levels "Know" (remembering) and "Applying". This may be appropriate in the context of a grade-oriented school model with primary school pupils, but it cannot work in adult education, as it denies adults their ability to reflect and assess. Even people with a very low level of basic digital competence must be enabled to carry out basic analysis, assessment and design processes in the digital sphere of action.

The European Digital Competence Framework for Citizens (DigComp) is a Digital Competence Framework with digital competence descriptors for all levels of learners needed for employment, personal development and social inclusion to improve access to lifelong learning (CARRETERO et al. 2017). In the "DigComp 2.1" model, which is similarly structured in terms of content and currently very popular in Europe, basic operating skills such as user interface paradigms such as menus, wish-washing/swiping or the activation of input fields by tapping are implicitly assumed. In the DigComp 2.1 eight proficiency levels for each competence have been defined through learning outcomes (using action verbs, following Bloom's taxonomy). Five competence areas have been outlined in the framework: Information and data literacy, communication and collaboration, digital content creation, safety as well as problem solving. All areas of competence are differentiated into three to six sublevels, making a total of 21 areas of competence. Each of them is supplemented by the aforementioned eight hierarchically structured proficiency levels (CARRETERO et al., 2017; 
KLUZER \& PUJOL PRIEGO, 2018). However, proficiency level 1, in which one is enabled to solve "simple tasks with support" on a cognitive process level "remembering", cannot be regarded as an educational goal of a basic digital literacy in adult education. These problems are addressed as follows in the Austrian adaptation "DigComp 2.2 AT" (Federal Ministry of Digitization and Business Location, 2018):

On the one hand, a competence field "0. basics and access" is added, which defines basic digital competences. On the other hand, a level between 3 and 4 is aimed at the digital everyday competence of adults and a level 5 for the media education of their own children. In existing competence models, the level of requirements is modelled less on the complexity of the tasks and more on cognitive performance levels. Here, the LEO study provides a new approach by differentiating between functional-pragmatic as well as cri-tically questioning digital competences and by orienting the questions to current everyday tasks (BUDDEBERG \& GROTLÜSCHEN 2020). However, the LEO study is less concerned with modelling digital competences than with putting written, non-written and digital practices into relation and thus does not provide a competence model for the area of basic digital literacy.

DigComp 2.1 is intended to be valid for all participants in society. Its fundamental basis expands the horizon of other concepts, which move within the school context, to a society-wide level. DigComp 2.1 also offers examples of use applied to employment and education in the form of infographics and visual guides (European Commission, 2017). The framework can also be used for self-evaluation, for setting learning goals, identifying training opportunities and assisting in job search. By using five areas of the DigComp framework, the Europass $\mathrm{CV}$ includes an online tool for jobseekers. It helps to self-evaluate one's digital competence and to describe and include it in the Curriculum Vitae (CV) (EUROPEAN COMMISSION, 2020). The focus is therefore on achieving an ever higher public transparent competence profile.

The results of the international comparative studies show that the focus of digital competence is on technical use and the lowest level is empirically not sufficiently differentiated. Empirical objective models only focus on a small section of media competence. Therefore, they can only be used for parts of a basic digital literacy. Thus, there should also be lower levels for the objective modelling of empirically measurable basic digital 
competences analogous to the alpha levels ${ }^{1}$ for reading and writing in the LEO model (GROTLÜSCHEN \& BUDDEBERG 2020).

Considering the idea of competence and the functions of competence models, there are two major problems with the use of competencies in education. Firstly, competencies approaches are essentially behavioristic and accordingly are not equipped to "...capture and describe something which is essentially non-behavioristic, namely the development of knowledge and understanding" (HYLAND, 1993, 61). For Hyland learning is far too complex and multifaceted to be broken down into verifiable performance indicators. The second problem is that performance indicators measures competence in a time and context-specific way.

\section{Interim conclusion I}

Competences and also digital competences can be seen as "bundles of skills". Competence frameworks have a normative perspective that could be suitable for anyone who needs thematic standards. The content of the competence models is highly connected to the technique and the thresholds which are defined by the society. Empirical-objective models always focus on only one sub-area, whereby the skill requirements for social participation are considerably more complex. In these models, the level of requirements is modelled not so much on the complexity of the tasks or learning causes, but rather on cognitive performance levels. Moreover, the lowest level of the existing competence models is not differentiated enough. The skills dimension of basic digital literacy also brings with it the challenge that purely material approaches must be continually adapted and revised and cannot be used in different socio-cultural contexts. For a concept of basic digital literacy its fruitful to integrate relevant domains to give an orientation for trainer and teachers but additionally a relative perspective has to be considered.

\section{The Relativist View - The Concept of (digital) Literacy}

In comparison to school education, adult education is characterized, among other things, by the fact that the learning content is geared to the interests and needs of the participants or learners. Strongly standardised curricula with objectively verifiable learning content are implemented less in general adult education and if so then only in the context of

\footnotetext{
${ }^{1}$ The alpha-levels were developed for a competence model for reading and writing. They comprise 6 successive levels (Grotlüschen \& Buddeberg 2020).
} 
formally recognized qualifications to be acquired. In the context of basic education processes for adults, the focus is on enabling participants to participate in society. What such participation in society involves must be determined before the socio-cultural context. In addition, the previous chapter made it clear that in order to determine a basic digital literacy it is not sufficient to consider objectively testable content, but that it is necessary to include both relationally interpretable content and formal aspects (interdisciplinary methodological and functional content). In order to make this approach fruitful for a basic digital literacy, the concept of literacy will be discussed below, followed by the concept of digital literacy.

\section{The Literacy Concept}

The originally purely functionalist view of literacy (functioning in society) was replaced by an active and proactive understanding of literacy (participation in society) (cf. BELLMANN, 2007, p. 426; WOLF \& KOPPEL, 2017, p. 5) with the focus on the usage of written language in everyday lives.

Many definitions and concepts of literacy exist. They can be localized in a broad way on a scale from limited and expanded concepts. The limited ones define literacy as the ability to read and write. Nowadays we read and write in different ways, also with digital media. With the shift in English-speaking countries towards New Literacy Studies, additional anthropological and intercultural perspectives are included, and literacy is understood as a continuum (LINDE, 2006, p. 96f.). In addition, the extended concepts focus on communication processes (UIL 2017; ELINET 2016), critical thinking, independent action and the ability to interact (STREET 2005; TRÖSTER \& SCHRADER 2016) with the aim to participate in society (UNESCO 2017, MONTOYA, 2018).

Following the extended approach literacy is defined as "the ability to identify, understand, interpret, create, communicate and compute, using printed and written materials associated with varying contexts. It involves a continuum of learning in enabling individuals to achieve their goals, to develop their knowledge and potential, and to participate fully in their community and wider society" (UNESCO, 2004; 2017; MONTOYA, 2018). Here, literacy is connected to participation in society as an overall goal and can be seen as a condition for participating successfully in social life.

Therefore, literacy is more understood as a social practice and as a set of social practice which can be inferred from events which are mediated by written texts. From this perspective, literacy is also seen as different literacies associated with different domains of life. The literacy practices are patterned by social institutions and power relationships, and 
some literacies are more dominant, visible and influential than others. They are purposeful and embedded in broader social goals and cultural practices. As Literacy is historically situated it changes and new ones are frequently acquired through processes of informal learning and sense making (BARTON and HAMILTON, 2000).

In conclusion, the concept of literacy can be regarded as a relational concept based on the skills needed to achieve one's goals and participate in society to one's satisfaction whereas descriptions of competences are rather content oriented.

\section{Digital Literacy}

The digital change in our society makes digital literacy a central concept of all areas of further education, which integrates itself into other learning subjects. As more and more areas of knowledge are acquired via digital media, digital literacy also represents a core foundation for each individual to successfully shape the process of lifelong learning (KILIAN, 2019). If the focus of competence models is on operationalizability and measurability, literacy concepts aim precisely to avoid a technologically deterministic view.

There is a wide range of digital literacy models, which are based on new or digital media (GRAFE, 2011; BAWDEN 2008). They range from pragmatically functional on participatory (see JENKINS, 2009) up to critical approaches (KAHN \& KELLNER, 2005; SELWYN, 2014).

The use of a computer, the use of the internet, making an appointment at your doctor's, telling your electricity company about your annual use via app, using online banking and so on is part of today's everyday life. Sometimes it gets more and more difficult to deal with people in person, but people are expected to use apps or online tools to gain certain information or to deal with their personal matters. A survey done by Statista on E-Health shows that 27 percent of people use at least one digital health device. It is also reported that the share of online appointments with doctors is increasing. Ireland is the country with the highest proportion of online appointments in Europe, with 52\% (Statista Content \& Design, 2020). This shows that the use of digital media is increasing and takes up an ever-larger part of our lives.

Likewise, the results of the Worldpay report state that ecommerce is expected to surpass USD 4.6 trillion globally by 2022, with 140 online payment methods in use today. According to the report, e-wallets have also gained a lot of popularity and online banking payments are also in the focus (The Paypers, 2019). In Brazil, for example, of all the banking transactions carried out in 2018, 40 percent took place via mobile banking in comparison to 
only 10 percent of transactions in 2014. Digital communications have also grown considerably in Brazilian banking, with web chat interactions up 364 percent and customer service requests handled by chatbots growing considerably from 3 million in 2017 to 80.6 million in 2018 (MARI, 2019).

On the one hand, these examples show that the definition of what someone calls "digital literate" depends on the social and the cultural context. On the other hand, they show that the use of apps and online tools or digital media in general is indispensable in today's society and that their use is likely to increase: "Social information is received via the Internet and if you are not able to locate information, let alone evaluate it, you can easily fall victim to all kinds of fake news and vote catching. Our society cannot want that. And people who can't inform themselves are in danger of being further and further cut off from the media and society" (SCHAUMBURG interviewed by GÖTZKE 2020).

At the conference "Educating for the Media and the Digital Age" there were six principles developed by 41 media educators and researchers from 33 countries. They provided UNESCO with a recommendation for a worldwide media literacy program based on the following principles:

- integration of all media;

- every citizen should have the opportunity for participation;

- understanding the media system and how it functions;

- analyzing and reflecting media messages;

- access to media and production of media messages as a precondition for reaching the mentioned goals;

- ability to communicate and formulate one's own needs (VON FEILITZEN, 2002, p. 53).

These principles cover national differences, which are expressed in the different forms of media education and which react strongly to regional and cultural conditions (Hart, 1998) hence the goal of digital literacy is not so much linked to operationalized descriptions of competences but must be filled out according to the respective countries and cultures. This recommendation covers not only the skills in dealing with digital media (analyzing, understanding, communicating and formulating) but also the prerequisites (access to media) required for the aims (integration of all media and participating).

Reder suggests that we think of this process as a journey, and determine the path that an adult may take, and the preconditions for that pathway. REDER (2015) has proposed a 
four-stage pathway to digital inclusion: 1. Digital access, 2. digital taste, 3. digital readiness and 4. digital literacy.

Each of the four stages has its own barrier to overcome in order to move forward in the pathways to digital inclusion. Those who have never used a computer before are in the first phase: digital access. They need access to the needed technique - nowadays a computer or a mobile device. In digital access, the barrier is the lack of hardware or probably broadband. Once people have access to a computer, the second phase begins: digital taste, there it is important that adults are supported in identifying ways in which they can benefit from the digital world on their own terms and conditions, meaning, they decide on the purposes, they are going to use the computer for. In digital taste, a lack of confidence or even the desire to use digital gadgets at all might be a barrier.

According to MALLOWS (2020), this is where many initiatives fail as it is pointless to give an adult access to a computer if they do not want to use it. Think about an elderly relative who has been given an iPad as a gift, hoping that he or she will start writing emails instead of letters and keep in touch with family and enjoy the gadget. In a famous German TV show this is pointed out by showing what happened to the iPad granddad got for Christmas and he now uses this electronic gadget happily as a kitchen utensil by chopping onions on it.

Others, of course, soon notice the advantages of digital devices. After they have taken a liking to the digital world, the next step - digital readiness - becomes more important. They still lack the basic skills needed and are therefore not yet "ready" to use the technology, but their chances of success are much greater as they have already "digital taste". Reder follows HORRIGAN (2014) who defines digital readiness as the combination of trust in and skills needed to use powerful new applications in health care, education, commerce and government service delivery. The digital readiness describes a continuous process of development in learning the skills to use the computer. Accordingly, the barrier is basic IT skills.

On the basis of the results of the PIAAC study, it can be assumed that adults with a low literacy level tend to have less computer experience and thus also a low level of media competence (WOLF \& KOPPEL, 2017). A national German study by the University of Hamburg, Germany, takes this approach into account regarding the individual perspective. The study shows that people with low literacy trust less in their abilities concerning relevant internet practices compared to literate people: 6498 people between the ages 18 to 64 (employable age) were asked about their experience with digital media. The results were shown in percentages of people who do not feel confident enough or only with great difficulty 
e.g. to deal with online job sites, online dating sites or online housing markets. Compared to the total population, people of low literacy (defined by Alpha levels $1-3^{2}$ ) have about three times as much difficulty. Regarding the use of computers with Internet access, 55\% of people with low literacy use them regularly (daily or at least once a week) compared to $82 \%$ of the total population. On the other hand, $78 \%$ of people with low literacy use Internet-enabled mobile phones, smartphones or tablets regularly (daily or at least once a week) compared to $89 \%$ of the total population. In summary the study shows that people with a low literacy level use smartphones in daily life, but use fewer digital practices (e.g. email writing) and have less confidence in using online platforms than people with a higher literacy level (BUDDEBERG \& GROTLÜSCHEN 2020, 214). This leads to a higher risk of social exclusion.

Once they have acquired satisfactory skills and are now doing what they want to do, they are "ready for the digital world" and can move on to the final phase: digital literacy. This stage is a continuous process of development in which people are not automatically digitally literate concerning specific criteria often associated with that terminology. They are mainly involved in further developing their IT skills and proficiencies in problem-solving with them, having to overcome the barrier of fast developing digital technology and new inventions of applications (REDER, 2015; MALLOWS, 2020). In this stage they need to systematically develop their skills in using digital tools as they navigate to what they enjoy doing (REDER, 2015).

Digital literacy is described as a social practice that not only involves encoding and coding, but also includes the social and anthropological dimension of computer interaction (LANKSHEAR \& KNOBEL, 2008; p. 9ff.; quoted after PIETRAß 2010, p. 73). Compared to the concept of competence digital literacy is more than the ability to use digital sources effectively; it is a special kind of mindset or thinking (ESHET, 2002; GILSTER, 1997). More precisely, ELINET indicates the following characteristics of digital literacy:

Digital Literacy is transversal to many different activities: it is about making "confident, critical and creative use of diverse digital devices to achieve goals related to work, employability, learning, leisure, inclusion and/or participation in society.

Digital Literacy is part of everyday literacy: that is to say, it can be viewed as both similar to and different from traditional literacy. To read and write digitally, students and teachers must learn to create and interpret texts in diverse modes (such as static and moving images and icons, spoken and written language, screen layout etc.), and to navigate texts

\footnotetext{
${ }^{2}$ The Alpha levels 1-3 describe the lower levels of competence. Persons who are in the first three levels in terms of their reading and writing skills are referred to as persons with low literacy.
} 
across diverse digital platforms which offer a variety of learning opportunities, formats for creation, and spaces for expression that were not previously available.

Digital Literacy is a complex and socio-culturally sensitive issue: it is much more than the capacity to use ICT tools, but should be regarded as a set of social and sense-making competences associated with interacting with a range of digital devices, where the central issue is about the diverse literacies needed to communicate and collaborate with others and to find and make sense of the available information" (ELINET, 2016b).

The description of ELINET highlights the importance of this approach for participation in society and shows that digital literacy comprises more than just defined areas of competence. This was considered by MARTIN \& GRUDZIECKI $(2006,255)$, they suggest the following definition:

"Digital literacy is the awareness, attitude and ability of individuals to appropriately use digital tools and facilities to identify, access, manage, integrate, evaluate, analyze and synthesize digital resources, construct new knowledge, create media expressions, and communicate with others, in the context of specific life situations, in order to enable constructive social action; and to reflect upon this process".

Jenkins has a similar perspective: Instead of solely highlighting individual attributes JENKINS (2006, p. 4) frames new media literacies ${ }^{3}$ as cultural competences and social skills that are developed through collaboration and networking. He differentiates the literacy approach in defining eleven new skills:

1. Play: the capacity to experiment with one's surroundings as a form of problem-solving;

2. Performance: the ability to adopt alternative identities for the purpose of improvisation and discovery;

3. Simulation: the ability to interpret and construct dynamic models of real-world processes;

4. Appropriation: the ability to meaningfully sample and remix media content

5. Multitasking: the ability to scan one's environment and shift focus as needed to salient details;

6. Distributed Cognition: the ability to interact meaningfully with tools that expand mental capacities;

7. Collective Intelligence: the ability to pool knowledge and compare notes with others toward a common goal;

\footnotetext{
3 "New media literacy" can be used synonymously with "digital literacy" in this context - even if the term "new media" makes it clear that new media do not have to be just digital media and can take on different forms depending on technical developments.
} 
8. Judgement: the ability to evaluate the reliability and credibility of different information sources;

9. Transmedia Navigation: the ability to follow the flow of stories and information across multiple modalities;

10. Networking: the ability to search for, synthesize, and disseminate information;

11. Negotiation: the ability to travel across diverse communities, discerning and respecting multiple perspectives, and grasping and following alternative norms.

In brief, Jenkins' approach avoids a technologically deterministic viewpoint and, moreover, opens up the skills debate to a number of underpinning but crucial skills and competences such as experimentation, problem-solving capabilities or the ability to pool knowledge and move towards a common goal with others (IORDACHE, MARIËN \& BAELDEN, 2017, p. 11). An analysis of 13 concepts of digital literacy (IORDACHE, MARIËN \& BAELDEN, 2017) shows that Jenkins' concept comparatively includes many areas of ability and starts from the question of social participation.

It should be critically noted that Jenkins' concept is to be understood as a culturalscientific description of a phenomenon. His enumeration remains without internal or external structuring. Therefore, it might be helpful to summarize and reduce the components of a digital literacy for a more systematic consideration, as Bawden has done (BAWDEN 2008). He discussed the origin and development of the idea of "digital literacy" and derived these four components from many concepts of digital literacy (BAWDEN 2008, 29):

1. underpinnings: literacy per se, Computer / ICT literacy

2. background knowledge: the world of information, nature of information resources

3. central competencies: reading and understanding digital and non-digital formats, creating and communicating digital information, evaluation of information, knowledge assembly, information literacy, media literacy

4. attitudes and perspectives: independent learning, moral / social literacy

Compared to the other concepts of digital literacy, this concept illustrates that the different components are interconnected and built upon each other. He also combines the objective perspective by identifying and integrating relevant competence domains (underpinnings and central competencies) with the relative perspective by including aspects that can be interpreted against the socio-cultural background (background knowledge, attitudes and perspectives). 
The fourth component, and in particular the concept of "independent learning", appears to be particularly important for a relational-formal approach. In a constantly changing mediatized culture, the ability to self-determined, autonomous learning and problem solving is a (formal) key competence which must form the basis of a comprehensive literacy. Digital literacy approaches share this characteristic with other concrete literacy concepts such as health or financial literacy. Digital literacy, however, has a special position in that it includes methods of digital autonomous learning and the development of digital innovation processes, which are also central to other literacy concepts.

As the term "underpinning" in BAWDEN'S concept (2008) and the last sentence indicate, a concept of digital literacy must include the preconditions. This is done by only a few concepts and leads to the beginning of this chapter: the digital inclusion pathway and its three first stages.

Equally importantly, a particular model of digital literacy may not be appropriate for all people, or even just for one person throughout their lives. Updating of understanding and competence will be increasingly necessary as individual circumstances change and changes in the digital information environment require new knowledge and skills. BAWDEN concludes that literacy can also be seen as a framework " [...] for the integration of various other literacy skills and abilities, even if it does not have to cover them all" (BAWDEN, 2008, p. 28).

\section{Interim conclusion II:}

Digital literacy represents a key competence for self-determined participation in mediatized cultures. The requirements for an appropriate basic digital literacy are not derived technologically, but are to be derived from digital practices of social participation. For successful integration of digital media at an institutional level therefore the four phases to digital inclusion should be considered when coordinating programs. For the concept of basic digital literacy, the approach of BAWDEN shows, that a combination of an objective and a relative perspective is possible. Against the background of the discourse discussed here, we join BAWDEN in proposing that digital literacy includes basic IT skills, background knowledge about the information society, key basic skills, attitudes and perspectives.

\section{Model of Basic Digital Literacy}

As pointed out above, both approaches, the objective and the relative, have their strength und their different characteristics. Even if some approaches - mainly the objective 
ones - differentiate levels, it is not possible to deduce only from this what a basic digital literacy comprises because the objective deterministic view does not allow an individual perspective. But as discussed above, the "overall" aim of literacy is participating in society and this depends on the socio-cultural background. Hence, we want to suggest a model, which takes this perspective into account and which also gives a clear orientation of what is needed. To reach this aim the digital inclusion pathway (REDER 2015) with the prerequisites and the individually designable stages can be used as structure. The four components of BAWDEN (2008) can be integrated in this structure. Both concepts can be merged to a model of "basic digital literacy". to a model of "basic digital literacy":

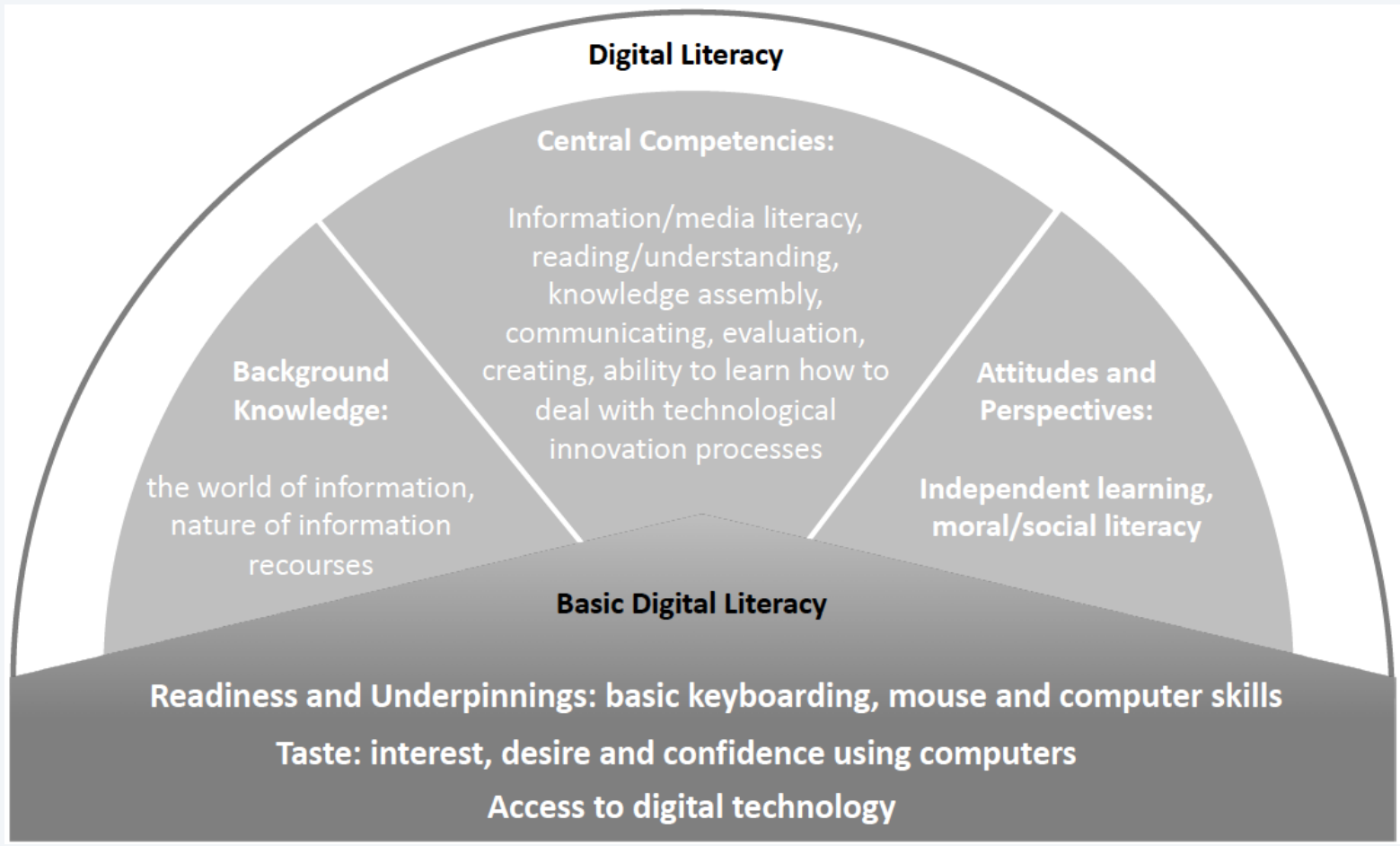

Figure 1: Model of Basic Digital Literacy (own representation based on BAWDEN (2008) and REDER (2015))

The preconditions for digital literacy are the access, the taste and the readiness. As "underpinnings" (BAWDEN, 2008) and the step "Readiness" (REDER, 2015) describe a similar content, we decided to bring them together. These three preconditions are ordered hierarchically, because the lower level is a requirement for the higher one.

Against this background the three components - background knowledge, central competences, attitudes and perspectives - unfold. As explained above, we suggest adding to the component "central competencies" the "ability to learn how to deal with technical innovation processes". In this area, we deliberately avoid hierarchies to consider that the 
characteristics are individual and do not develop linearly. This approach also allows the recognition of culturally different developments and influences. Accordingly, we refrain from a definition with operationalized content and we propose a description that can be used regardless of the state of technical and social development and regardless of the cultural context. Nevertheless, it offers criteria that can be interpreted and, if necessary, operationalized depending on the social context.

\section{Conclusion}

The current discourse shows that a basic digital literacy is necessary for people to participate in society. The objective view with his competence models might give some hints for the question, how elements of digital literacy can be operationalized. But considering the understanding of literacy and the characteristics of digital media, a relative approach with the possibility to interpret basic digital literacy for the individual background and time is needed. On the one hand there are different definitions of "digital literacy", areas of digital literacy are emerging and are embedded in most models. On the other hand, most models do not consider the fact that the preconditions for developing digital literacy need to be established in the first place. These should be included in a model for basic digital literacy. In this paper, a model for basic digital literacy was developed from existing models and concepts: The model of basic digital literacy includes the prerequisites for the use of digital media ("access", "taste", "readiness and underpinnings") as well as the digital-related skills (in the areas of "background knowledge", "central competences" and "attitudes and perspectives") that are required for participation in society. The model presented here represents a first cornerstone for constructively advancing the discourse on basic digital literacy and contributing to the implementation of basic digital literacy.

\section{REFERENCES}

BARTON, D. and HAMILTON, M. 'Literacy practices' in Barton, D., Hamilton, M. and Ivanič, R. (eds) Situated Literacies: reading and writing in context, London, Routledge, pp. 10-11. 2000.

BAWDEN, D., Origins and Concepts of Digital Literacy. In: Lankshear, C./Knobel, M., eds. Digital Literacies. Concepts, Policies and Practices. New York: Peter Lang. pp. 17-32. 2008.

BELLMANN, J., Der Pragmatismus als Philosophie von PISA? Zeitschrift für Erziehungswissenschaft. 10(3), 421-438. 2007. 
BMBF and KMK, Grundsatzpapier zur Nationalen Dekade für Alphabetisierung und Grundbildung 2016-2026. 2007. [Accessed: 20 February 2020] Available from:

https://www.bmbf.de/files/16-09-07\%20Dekadepapier.pdf.

BUDDEBERG, K., Digitale Praktiken und Grundkompetenzen. Alpha-Dekade-Konferenz, Hamburg. 2019.

CARRETERO, S.; VUORIKARI R. and PUNIE, Y., DigComp 2.1: The Digital Competence Framework for Citizens with eight proficiency levels and examples of use. EUR 28558 EN, [Viewed 9 February 2020]. Available from: doi:10.2760/38842. 2017.

COULDRY, N. and HEPP, A., The Mediated Construction of Reality. Cambridge: Polity Press. 2016.

ESHET, Y., Digital literacy: A new terminology framework and its application to the design of meaningful technology-based learning environments. In P. Barker and S. Rebelsky, eds. Proceedings of the World Conference on Educational Multimedia, Hypermedia and Telecommunications, pp. 493-498. Chesapeake VA: AACE. 2002. [Viewed 30 November 2007]. Available from: http://infosoc.haifa.ac.il/DigitalLiteracyEshet.doc.

EUROPEAN COMMISSION, Key Competences for Lifelong Learning. European Reference Framework. 2007. [Viewed 20 February 2020]. Available from:

https://www.erasmusplus.org.uk/file/272/download.

EUROPEAN COMMISSION, Education and Training 2020. Improving Policy and Provision for Adult Learning in Europe. 2015.

EUROPEAN COMMISSION, Learning to swim in the Digital Ocean: new DigComp report develops proficiency levels in detail. 2017. [Viewed 8 February 2020]. Available from:

https://ec.europa.eu/jrc/en/science-update/new-digcomp-report-develops-proficiency-levels.

EUROPEAN COMMISSION, DigComp. Being digitally competent - a task for the $21 \mathrm{st}$ century citizen. 2020. [Viewed 8 February 2020]. Available from:

https://ec.europa.eu/jrc/en/digcomp.

EUROPEAN LITERACY POLICY NETWORK (ELINET) European Declaration of the Right to Literacy. 2016a. [Viewed 4 February 2020]. Available from:

http://www.elinet.eu/fileadmin/ELINET/Redaktion/user_upload/European_Declaration_of_th e_Right_to_Literacy2.pdf.

EUROPEAN LITERACY POLICY NETWORK (ELINET), ELINET position paper on Digital Literacy. 2016a [Viewed 4 February 2020]. Available from:

http://www.elinet.eu/fileadmin/ELINET/Redaktion/Amsterdam_conference/ELINET_Positio n_Paper_on_Digital_Literacy.pdf.

EUROPEAN PARLIAMENT AND EUROPEAN COUNCIL Recommendation of the European Parliament and of the Council of 18 December 2006 on key competences for lifelong learning. 2006. [Viewed 3 February 2020]. Available from:

https://eur-lex.europa.eu/LexUriServ/LexUriServ.do?uri=OJ:L:2006:394:0010:0018:en:PDF.

FEILITZEN, C. von, Medienerziehung - Einige internationale Aspekte, Medien + Erziehung, 1. pp. 49-55. 2002.

GILSTER, P., Digital literacy. New York: Wiley. 1997. 
GÖTZKE, M., Digitale Analphabeten. Warum Schüler in Deutschland auf Fake News hereinfallen. 2020. [Viewed 17 February 2020]. Available from:

https://www.deutschlandfunk.de/digitale-analphabeten-warum-schueler-in-deutschlandauf.724.de.html?dram:article_id=469899.

GRAFE, S., „media literacy“ und „media (Iiteracy) education“ in den USA: ein

Brückenschlag über den Atlantik. In H. Moser, P. Grell, and H. Niesyto, eds. Medienbildung und Medienkompetenz: Beiträge zu Schlüsselbegriffen der Medienpädagogik. München:

Kopaed. 2011.

GROTLÜSCHEN, A., BUDDEBERG, K., DUTZ, G., HEILMANN, L. and STAMMER, C., LEO 2018 - Leben mit geringer Literalität. Universität Hamburg. 2019.

GROTLÜSCHEN, A.; MALLOWS, D.; REDER, S. and SABATINI, J., “Adults with Low Proficiency in Literacy or Numeracy", OECD Education Working Papers, No. 131, OECD Publishing, Paris. 2016. [Viewed 9 February 2020]. Available from:

http://dx.doi.org/10.1787/5jm0v44bnmnx-en.

HART, A., Introduction: media education in the global village. In: A. Hart, ed. Teaching the Media: international perspectives. London: Lawrence Erlbaum. pp. 1-21. 1998.

HAYLAND, T. Competence, Knowledge and Education. Journal of Philosophy of Education, 27(1), 57-68. 1993.

HELBIG, C. and HOFHUES, S., Leitideen in der medienpädagogischen

Erwachsenenbildung: Ein analytischer Blick. MedienPädagogik: Zeitschrift für Theorie und Praxis der Medienbildung. 30(0), 1-17. 2018. [Viewed 9 February 2020]. Available from:

https://doi.org/10.21240/mpaed/30/2018.02.26.X.

HORRIGAN, J. B. Digital readiness: Nearly one-third of Americans lack the skills to use next-generation 'Internet of things' applications. 2014 [Viewed 9 February 2020]. Available from:

https://jbhorrigan.weebly.com/uploads/3/0/8/0/30809311/digital_readiness.horrigan.june2014. pdf

HUGGER, K.-U. Medienkompetenz. In U. Sander, F. V. Gross and K.-U. Hugger, eds. Handbuch Medienpädagogik. Wiesbaden: VS Verlag für Sozialwissenschaften. pp. 93-99. 2008.

IORDACHE, C., MARIËN, I. and BAELDEN, D., Developing Digital Skills and Competences: A Quick-Scan Analysis of 13 Digital Literacy Models. Italian Journal of Sociology of Education. 9(1), 6-30. [Viewed 20 February 2020]. Available from: doi: 10.14658/pupj-ijse-2017-1-2. 2017.

JENKINS, H., Confronting the Challenges of Participatory Culture: Media Education for the 21st Century (Occasional paper on digital media and learning). The John D. and Catherine T. MacArthur Foundation. 2006. [Viewed 7 February 2020]. Available from:

https://www.macfound.org/media/article_pdfs/JENKINS_WHITE_PAPER.PDF.

JENKINS, H., Confronting the Challenges of Participatory Culture. London: MIT Press. 2009.

KAHN, R., and KELLNER, D., Oppositional politics and the Internet: A critical/reconstructive approach. Cultural Politics. 1(1), 75-100. 2005. 
KAMIN, A.-M. and MEISTER, D. M., Medienpädagogik in Institutionen der Erwachsenenund Weiterbildung. In D. M. Meister, F. von Gross and U. Sander, eds. Enzyklopädie Erziehungswissenschaft Online. Weilheim/München: Juventa. 2013.

KERRES, M., Mediendidaktik. Konzeption und Entwicklung mediengestützter Lernangebote. München: Oldenbourg. 2013.

KILIAN, L., "Digital Literacy" - Versuch einer Begriffsbestimmung. 2019. [Viewed 2 March 2020]. Available from:

https://wb-web.de/aktuelles/digital-literacy-versuch-einer-begriffsbestimmung.html.

KLUZER S. and PUJOL PRIEGO L., DigComp into Action - Get inspired, make it happen.

S. CARRETERO, Y. PUNIE, R. VUORIKARI, M. CABRERA and O'KEEFE, W., eds. JRC Science for Policy Report, EUR 29115 EN, Publications Office of the European Union, Luxembourg, 2018. [Viewed 9 February 2020]. Available from: doi:10.2760/112945.

KOPPEL, I., Entwicklung einer Online-Diagnostik für die Alphabetisierung - Eine DesignBased Research-Studie. Wiesbaden: Springer VS. 2017.

LANKSHEAR, C. and KNOBEL, M. eds., Digital Literacies. Concepts, Policies and Practices. New York. 2008.

LIN, M.-H., CHEN, H.-C. and LIU, K.-S., A Study of the Effects of Digital Learning on Learning Motivation and Learning Outcome. Journal of Mathematics Science and Technology Education. 13(7), 3553-3564. 2017.

LINDE, A., Alphabetisierung, Grundbildung oder Literalität? In A. Grotlüschen and A. Linde, eds. Literalität, Grundbildung oder Lesekompetenz? Beiträge zu einer Theorie-PraxisDiskussion. $1^{\text {st }}$ edition. München: Waxmann. pp. 90-99. 2006.

MALLOWS, D., A digital inclusion pathway. Blog. EPALE (Electronic Platform for Adult Learning in Europe), ed. 2020. [Viewed 7 February 2020]. Available from:

https://epale.ec.europa.eu/en/blog/digital-inclusion-pathway.

Mari, A., Mobile accounts for nearly half of all banking transactions in Brazil. 2019. [Viewed 7 February 2020] Available from:

https://www.zdnet.com/article/mobile-accounts-for-nearly-half-of-banking-transactions-inbrazil/

MARTIN, A. and GRUDZIECKI, J. DigEuLit: Concepts and Tools for Digital Literacy Development, Innovation in Teaching and Learning in Information and Computer Sciences, 5:4, 249-267. 2006.

MARTIN, A., Literacies for the digital age. In A. Martin and D. Madigan eds. Digital literacies for learning. London: Facet Publishing. 2006

MONTOYA, S., Defining Literacy. GAML Fifth Meeting 17-18 October 2018, Hamburg, Germany. UNESCO Institute for Statistics, ed. 2018. [Viewed 17 February 2020]. Available from: http://gaml.uis.unesco.org/wp-content/uploads/sites/2/2018/12/4.6.1_07_4.6-definingliteracy.pdf.

NATIONAL TRAINING STRATEGY. 2019. [Viewed 27 February 2020]. Available from:

https://www.bmbf.de/de/nationale-weiterbildungsstrategie-8853.html.

OECD The Definition and Selection of Key Competencies. Executive Summary. OECD

Publishing 2005. [Viewed 7 February 2020]. Available from: 
https://www.oecd.org/pisa/35070367.pdf.

OECD Literacy, Numeracy and Problem Solving in Technology-Rich Environments: Framework for the OECD Survey of Adult Skills. OECD Publishing. 2012. [Viewed 7 February 2020]. Available from:

http://dx.doi.org/10.1787/9789264128859-en.

PIETRASS M., Digital Literacies. In B. Bachmair, ed. Medienbildung in neuen Kulturräumen. Wiesbaden: VS Verlag für Sozialwissenschaften. pp. 73-86. 2010.

PIETRASS, M., Medien. In J. Dinkelaker and A. von Hippel, eds. Erwachsenenbildung in Grundbegriffen. Stuttgart: Kohlhammer. pp. 150-157. 2015.

RAMMSTEDT, B. ed., Grundlegende Kompetenzen Erwachsener im internationalen Vergleich. Ergebnisse von PIAAC 2012. Münster: Waxmann. 2013.

REDER, S., Digital Inclusion and Digital Literacy in the United States: A Portrait from PIAAC's Survey of Adult Skills. 2015. [Viewed 22 January 2020]. Available from:

https://static1.squarespace.com/static/51bb74b8e4b0139570ddf020/t/551c3e82e4b0d2fede648 1f9/1427914370277/Reder_PIAAC.pdf.

SCHNEIDER, K., What Does Competence Mean? Psychology, 10, 1938-1958. 2019. https://doi.org/10.4236/psych.2019.1014125.

SELWYN, N., Distrusting educational technology: Critical questions for changing times. New York: Routledge. 2014.

SPANTE, M., SOFKOVA HASHEMI, S., LUNDIN, M. and ALGERS, A., Digital competence and digital literacy in higher education research: Systematic review of concept use, Cogent Education. [Viewed 10 March 2020]. Available from:

https://doi.org/10.1080/2331186X.2018.1519143. 2018.

Statista Content \& Design, E-Health 2020. [Viewed 22 February 2020]. Available from:

https://content-design.statista.com/ehealth-infographic/.

STREET, B. V., Understanding and defining literacy. Background paper prepared for the Education for All Global Monitoring Report 2006 Literacy for Life. 2005. [Viewed 11 February 2020]. Available from: https://unesdoc.unesco.org/ark:/48223/pf0000146186.

STURM, A. ed., Literales Lernen von Erwachsenen im Kontext neuer Technologien. Münster: Waxmann. 2010.

TREUMANN, K. P., MEISTER, D. M., SANDER, U., BURKATZKI, E., HAGEDORN, J., KÄMMERER, M., WEGENER, C., Medienhandeln Jugendlicher - Mediennutzung und Medienkompetenz. Bielefelder Kompetenzmodell. Wiesbaden: Springer VS. 2007.

THE PAYPERS, Payment Methods Report 2019. Innovations in the way we pay. 2019. [Viewed 20 February 2020]. Available from:

https://www.europeanpaymentscouncil.eu/sites/default/files/inline-files/Payment\% 20Methods\%20Report\%202019\%20-\%20Innovations\%20in\%20the\%20Way $\% 20 \mathrm{We} \% 20$ Pay.pdf.

TRÖSTER, M. and SCHRADER, J., Alphabetisierung, Grundbildung, Literalität: Begriffe, Konzepte, Perspektiven. In C. Löffler and J. Korfkamp, eds. Handbuch zur Alphabetisierung und Grundbildung Erwachsener. Münster: Waxmann. pp. 42-58. 2016. 
UNESCO, The Plurality of literacy and its Implications for Policies and Programmes. 2004.

[Viewed 17 February 2020]. Available from:

https://unesdoc.unesco.org/ark:/48223/pf0000136246.

UNESCO, Recommendation on adult learning and education 2015. Paris: UNESCO 2016.

[Viewed 20 February 2020]. Available from:

https://unesdoc.unesco.org/ark:/48223/pf0000245179.

UNESCO Institute for Lifelong Learning, Harnessing the Potential of ICTs for Literacy Teaching and Learning. Effective Literacy and Numeracy Programmes using Radio, TV, Mobile Phones, Tablets, and Computers. Hamburg: UNESCO. 2016. [Viewed 20 February 2020]. Available from: https://unesdoc.unesco.org/ark:/48223/pf0000243981.

UNESCO Institute for Lifelong Learning, 7 UIL Policy Brief 7. Literacy and Numeracy from a Lifelong Learning Perspective. 2017. [Viewed 17 February 2020]. Available from:

https://unesdoc.unesco.org/ark:/48223/pf0000247094.

VÁGVÖLGYI, R.; COLDEA, A.; DRESLER, T.; SCHRADER, J. and NUERK, H.-C., A Review about Functional Illiteracy: Definition, Cognitive, Linguistic and Numerical Aspects. Front. Psychol. 7:1617. 2016. [Viewed 24 February 2020]. Available from: doi:10.3389/fpsyg.2016.01617.

WOLF, K. D.; KOPPEL, I., Digitale Grundbildung: Ziel oder Methode einer chancengleichen Teilhabe in einer mediatisierten Gesellschaft? Wo wir stehen und wo wir hin müssen. In: Magazin Erwachsenenbildung.at. 2017.

\section{SOBRE AS AUTORAS:}

\section{Ilka Koppel}

Junior Professor of educational science, University of Education Weingarten, Germany.

Email: koppel@ph-weingarten.de langersa@ph-weingarten.de

(iD) http://orcid.org/0000-0001-6204-6379

\section{Sandra Langer}

Academic assistant, University of Education Weingarten, Germany. Email: langersa@phweingarten.de

iD http://orcid.org/0000-0003-2477-9912 